Int. J. Dev. Biol. 60: 85-93 (2016)

doi: $10.1387 / \mathrm{ijdb} .160083 \mathrm{yy}$

\title{
Hypoxia promotes thyroid differentiation of native murine induced pluripotent stem cells
}

\author{
YIPENG YANG ${ }^{1, \#,}$, YUNSHU LU 1,\#, TONG CHEN ${ }^{1}$, SHENGLAI ZHANG ${ }^{1}$, BINGFENG CHU ${ }^{1}$, YURONG GONG ${ }^{1}$, \\ WEIXIN ZHAO ${ }^{2}$, JIAN ZHU*,1 and YINGBIN LIU*,1 \\ ${ }^{1}$ General Surgery Department, Xin Hua Hospital of Shanghai Jiao Tong University School of Medicine, Shanghai, China \\ and ${ }^{2}$ Wake Forest Institute for Regenerative Medicine, Wake Forest School of Medicine, Winston Salem, NC, USA
}

\begin{abstract}
Hypothyroidism is a very common hormonal deficiency and the stem cell technology which developed in the recent years may offer a therapeutic strategy for treating this disorder. Hypoxia has been demonstrated to play an important role in embryonic formation and development and to modulate stem cell differentiation. However, the influence of oxygen tension on thyroid differentiation has not been studied. In this study, we used murine induced pluripotent stem (iPS) cells for thyroid cell differentiation under normoxic and hypoxic conditions and compared differentiation efficiency in morphology, function, gene and protein expression under both conditions. We found that hypoxia promoted adhesion and outgrowth of embryoid bodies (EBs) derived from murine iPS cells. Expression of endodermal markers (Foxa2 and Gata4) and thyroid transcription factors (Pax8 and Nkx2.1) was increased by hypoxia at both gene and protein levels during earlymid differentiation stages $(p<0.05)$. And so were the thyroid specific markers NIS and TSHR at the end of the experiment $(p<0.05)$. In addition, functional iodide uptake by differentiated cells was also increased after hypoxia. Thyroid differentiation from iPS cells is enhanced under hypoxia and this may involve hypoxia inducible factors (HIFs) and their downstream gene FGF2. Our data offer a foundation for understanding thyroid development and provide a potentially more efficient way to use cell therapy for treating thyroid deficiency.
\end{abstract}

KEY WORDS: differentiation, thyroid, hypoxia, promotion, iPS cell

\section{Introduction}

Thyroid gland produces two essential hormones which impact almost every organ and cell of the body and get involved in varieties of biological processes (Sewell et al., 2014). Hypothyroidism, an irreversible change (Ma et al., 2015), is the most common hormonal deficiency and can be precipitated by various diseases (Hollowell et al., 2002; McLachlan et al., 2004). Recently, stem cell technologies have advanced and provide a new strategy to treat thyroid deficiency by tissue engineering and regenerative medicine. Successful differentiation from murine embryonic stem cells (mESCs) to thyrocyte-like cells was first reported by Lin's group (Lin et al., 2003). Arufe and colleagues described directed derivation of thyroid follicular cells by ESCs and proved that thyrotrophin, insulin, and insulin-like growth factor-1 (IGF-1) were essential for this differentiation (Arufe et al., 2006; Arufe et al., 2009). For in vivo experiments, Antonica's groups generated functional thyroid follicular cells by mESCs which were modified to overexpress Nkx2.1 and Pax8 and rescue hypothyroid mice after implantation (Antonica et al., 2012). Although ESCs can differentiate into many cell types, perceived ethical and immunological problems restrict their practical application (Yamanaka, 2008). Induced pluripotent stem (iPS) cells from somatic mammalian cells via exogenous overexpression of Yamanaka factors (OCT3/4, KLF4, cMYC, and SOX2) are of interest and utility (Takahashi et al., 2007; Yamanaka, 2008). Indeed, Ma and colleagues transfected murine iPS cells with Nkx2.1 and Pax8 and differentiated them into thyroid follicular cells

Abbreviations used in this paper: DE, definitive endoderm; FGF2, fibroblast growth factor 2; HIF, hypoxia inducible factor; iPS cell, induced pluripotent stem cell; NIS, sodium iodide symporter; Tg, thyroglobulin; TPO, thyroperoxidase; TSHR, thyrotrophin receptor.

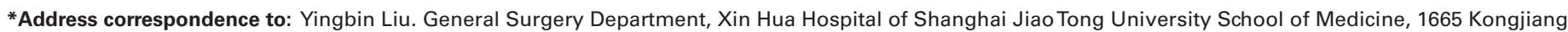

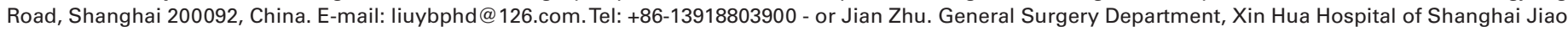
Tong University School of Medicine, 1665 Kongjiang Road, Shanghai 200092, China. E-mail: 69zj@ sina.com. Tel: +86-18918601360.
}

\#Note: These authors contributed equally to this work. 
(Ma et al., 2015).

The relatively hypoxic uterus is necessary for early formation and development of mammalian and human embryos (Dunwoodie, 2009; Fischer et al., 1993), and the influence of hypoxia on proliferation, differentiation and function of cells, especially in stem cells is of interest (Millman et al., 2009; Mohyeldin et al., 2010; Wion et al., 2009). Research indicates that culturing stem cells in a low oxygen environment better maintained pluripotent differentiation ability and reduced chromosomal abnormalities (Ezashi etal., 2005; Zachar et al., 2010). Hypoxia can enhance differentiation from stem cells of various cell types such as endothelial (Prado-Lopez et al., 2010; Shin et al., 2011) and neural cells (Mondragon-Teran et al., 2009) as well as retinal, lung, and heart progenitor cells (Bae et al., 2012; Garreta et al., 2014; van Oorschot et al., 2011). Therefore, we hypothesized that oxygen tension may influence differentiation into thyroid cells. In this study, we performed the thyroid induction with unmodified iPS cells which are safer in clinical application than virally transfected iPS cells with Nkx2.1/Pax8 by a new protocol. We mimicked physiological hypoxic environments and compared differentiation efficiency in morphology, function, gene and protein expression to normoxic condition. We found that the low oxygen tension could enhance the thyroid derivation from murine iPS cells (miPSC).

\section{Results}

\section{Embryoid body (EB) formation and adhesion under normoxia and hypoxia}

Fig. 1A, B showed murine iPS cell clones on irradiated MEF feeder cells. In our study, the suspension cultured miPS cells were able to form EBs in the EB induction medium under both hypoxic and normoxic conditions after 12-24 hours. EB size, density and numbers formed after 24 and $60 \mathrm{~h}$ were similar under both conditions (Fig. 1C-F). EB adhesion onto gelatin coated culture dishes and outgrowth after reattachment are necessary for further differentiation of iPS cells in our protocol. Thus, we compared EB adhesion ratios and cell morphology under both conditions and Fig. 1I showed that the hypoxia bar was higher but this was not statistically different (Fig. 1I.). Morphologically, EBs had better outgrowth and spread farther after reattachment under hypoxia during the same culture period (Fig. 1G, H, J). Therefore, hypoxia promoted adhesion and outgrowth of EBs but low oxygen does not influence the formation of EBs.

\section{Hypoxia promotes thyroid endoderm induction}

After EB formation, we used high concentration of Activin A (50ng $\mathrm{mL}^{-1}$ ) and gradually reduced FBS to induce the definitive endoderm (DE), the next step of thyroid differentiation from iPS cells. An anterior foregut endoderm was induced with a high concentration of NOGGIN (BMP signaling inhibitor) and SB-431542 (TGF- $\beta$ signaling inhibitor). In this study, We also supplemented differentiation medium with hTSH, mBMP4, mFGF2 and FGF10 for the induction of thyroid endoderm.

To measure gene expression, we isolated total RNAfrom cultured cells at specific times and quantitative real-time PCR confirmed that cells cultured under both conditions expressed Foxa2, Gata4 and Sox17-all endodermal markers (Mora-Castilla et al., 2014) from day 7 of differentiation (Fig. 2G). The levels of Gata4 and Foxa2 were much higher in hypoxia (more than 3 folds) on day 7 and 12 (Fig. 2G). But Sox17 expression under both culture conditions was similar on these two time points. mRNA expression of thyroid transcription factor 1 (TTF1, Nkx2.1) and Pax8 which were consider to be the crucial transcription factors to promote the expression of thyroid-specific genes (Mu et al., 2012) were also measured and these two factors were confirmed during the differentiation under both culture conditions and expression both was significantly upregulated with hypoxia in the endodermal stage (Fig. 3J).

With immuno-fluorescent staining, we confirmed that cells were positive for Foxa2 (located in the periphery of expanded EBs) on day 10 under both conditions (Fig. 2A-D). Foxa2-positive cells
miPS cells

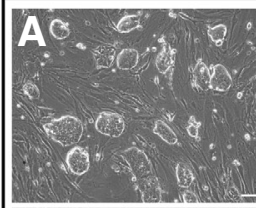

E.

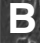

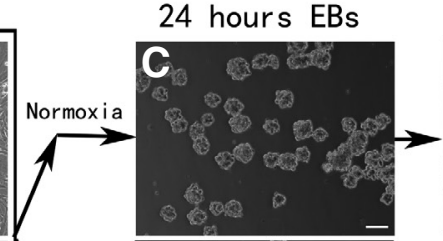

.

D
60 hours EBs
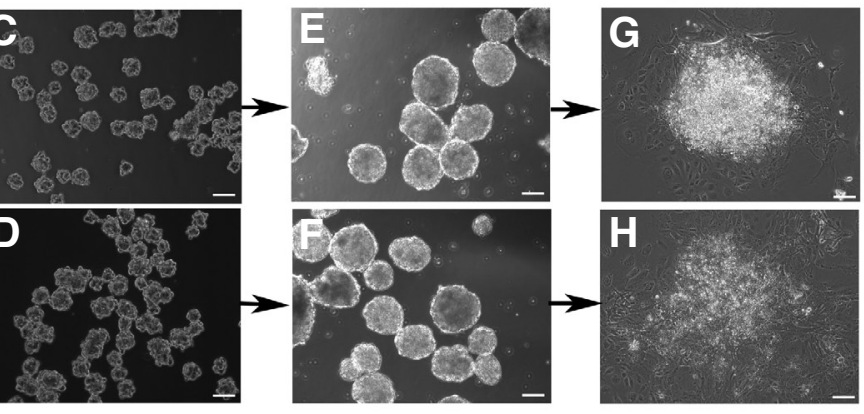
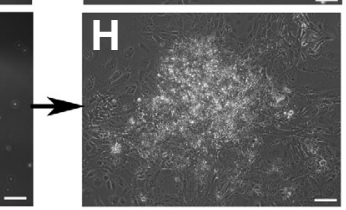

I

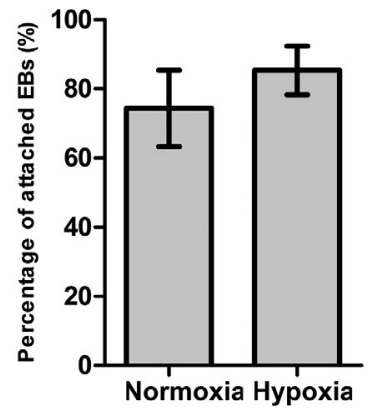

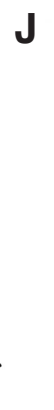

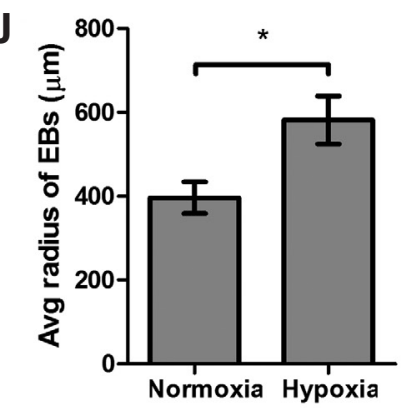

Fig. 1. Formation and adhesion of embryoid bodies (EB) under normoxic and hypoxic conditions. (A,B) Mouse iPS cell clones on irradiated MEF feeder cells under low and high magnification. (C,E) Suspension cultured EBs formed after 24 and $60 \mathrm{~h}$ under normoxia. (D,F) Suspension cultured EBs formed after 24 and 60 $h$ under hypoxia. $(\mathbf{G}, \mathbf{H})$ Expanded EBs on gelatin coated culture dishes 4 days after reattachment. (I) Percent EBs attached to gelatin-coated culture dishes underhypoxia or normoxia after 48 h of culture. Scale bars $=100 \mu \mathrm{m}$. (J) Average radius of expanded EBs 4 days after reattachment under hypoxia or normoxia. Significant differences exist between the two culture conditions. The results showed that hypoxia promoted adhesion and outgrowth of EBs. Data are from three independent experiments. * $(p<0.05, n=15)$. 

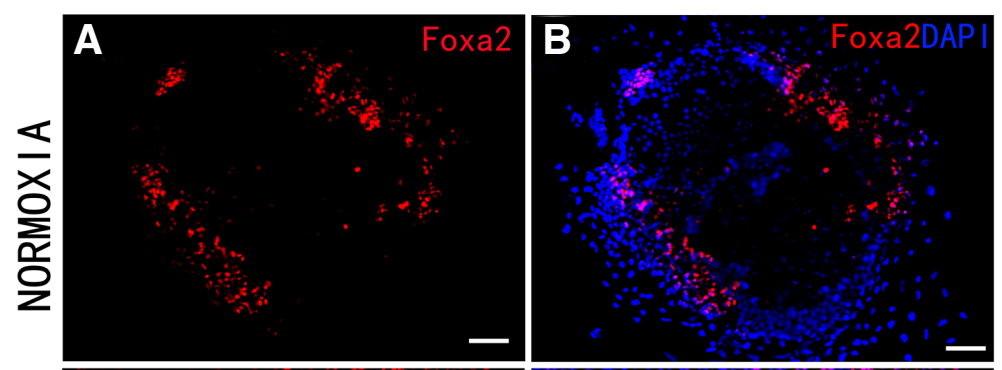

E
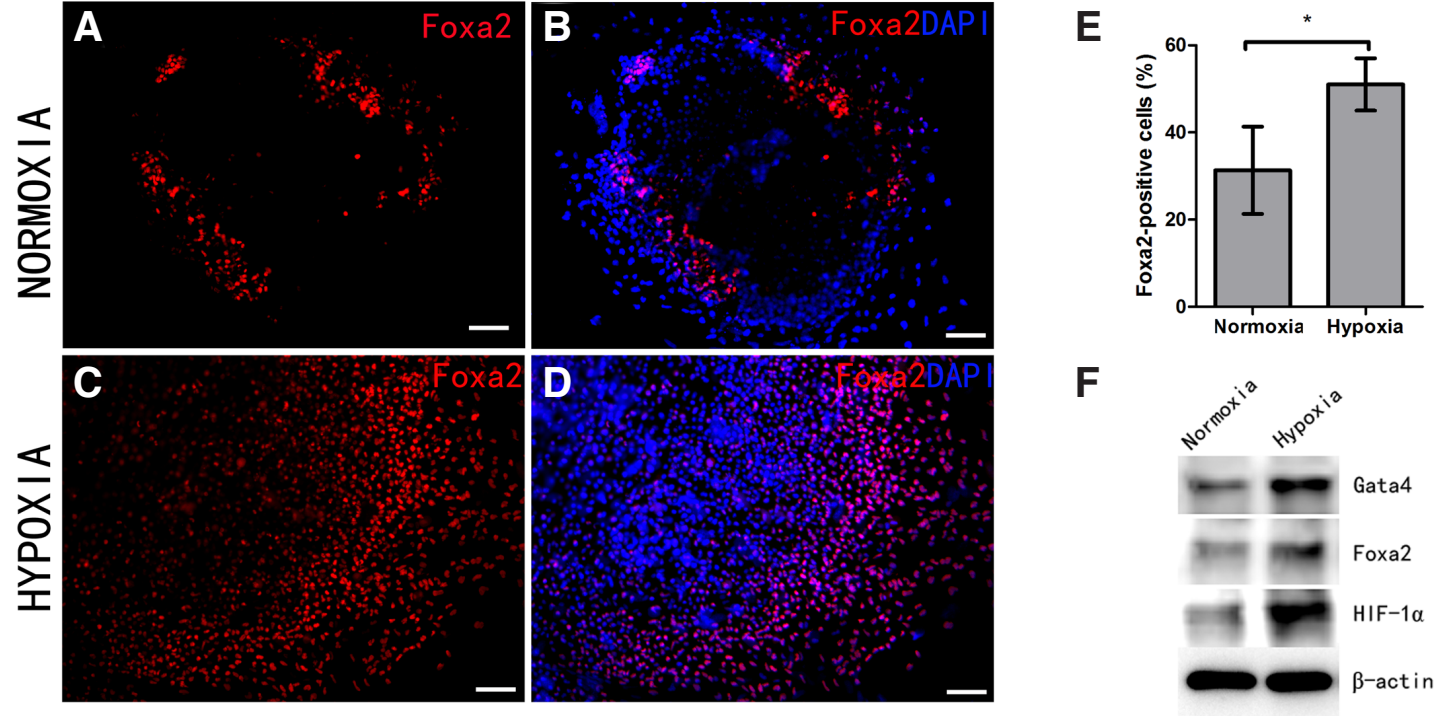

G
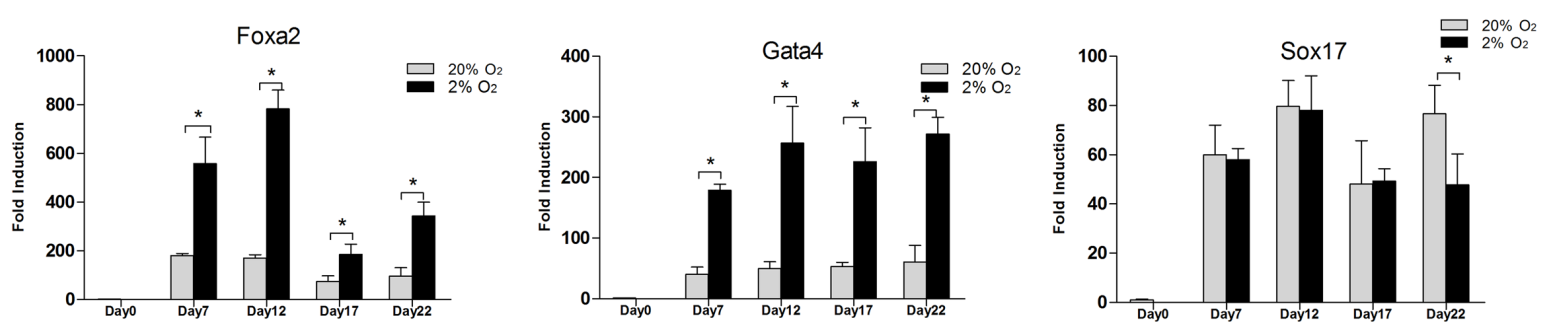

Fig. 2. Hypoxia enhances the expression of the endodermal markers. (A-D)Representative images of immuno-fluorescent staining for Foxa2 on day 10 of the differentiation process under hypoxia and normoxia. Scale bars $=100 \mu \mathrm{m}$. (E) Percent Foxa2+cells under hypoxia or normoxia. Significant differences exist between the two culture conditions. ${ }^{*}(\mathrm{p}<0.05)$. (F) Western blot analysis on day 12 of differentiation. $\beta$-actin was an internal control. (G) Expression levels of the endodermal markers Foxa2, Gata4 and Sox17 relative to undifferentiated miPS cells (day0) under hypoxic (black bar) and

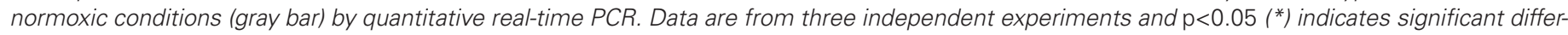
ences between groups.

under hypoxic conditions were greater than under normoxic culture (Fig. 2E, $p<0.05$ ). Cells that co-expressed Nkx2.1 and Pax8 potentially correspond to thyrocytes, so double-staining for these two markers was done on day 15 . We found the better outgrowth of the cell clusters than day 10 of differentiation and there were abundant Nkx2.1-positive and Pax8-positive cells in both culture conditions (Fig. 3). The percentage of Nkx2.1+ Pax8+ cells in hypoxia was significantly higher than in normoxia (Fig. $3 \mathrm{I}, p<0.05$ ). In addition, thyrotrophin receptor (TSHR) was expressed at the relatively early stage of differentiation in a similar area as Foxa2 and immuno-fluorescent staining confirmed stronger expression of TSHR protein under hypoxia (Fig. 4). Besides that, western blot data on day 10 confirmed increased Foxa2 and Gata4 protein expression in response to low oxygen tension (Fig. 2F). In summary, enhancement of thyroid endodermal markers expression occurs with hypoxia during this stage.

HIFs are important transcription factors that mediate cell responses to hypoxia ( $\mathrm{Ng}$ et al., 2010). HIFs contain several subtypes which can affect hundreds of downstream genes in differentiation and play a crucial role in embryonic development. Thus, we measured HIF- $1 \alpha$ and HIF-2 $\alpha$ expression under both conditions and quantitative realtime PCR data (Fig. 5) showed that hypoxia significantly increased expression of both HIF- $1 \alpha$ and HIF-2 $\alpha$ during thyroid differentiation $(p<0.05)$ and these increases were impressive during early stages of differentiation (Fig. 5E). Fig. 5E also confirmed down-regulation of HIF- $1 \alpha$ and HIF-2 $\alpha$ during the later differentiation period. The result of western blotindicated stronger expression of HIF-1 $\alpha$ protein was induced by hypoxia (Fig. 2F) and immuno-fluorescent staining for HIF- $1 \alpha$ on day 10 of differentiation indicated that HIF- $1 \alpha$ was expressed widely and strongly among cells with hypoxia but not as much with normal oxygen (Fig. 5A-D). As one of the important downstream genes of HIFs (Simon et al., 2008), fibroblast growth factor 2 (FGF2) is considered to be necessary for thyroid lineage specification from mouse pluripotent stem cells (Kurmann et al., 2015). In order to avoid the interference of exogenous factors, we measured mRNA expression of FGF2 under both conditions with HIFs and the resultindicated that hypoxia also significantly increased the level of FGF2 at all the time points (Fig. 5E).

\section{Hypoxia promotes the induction of thyroid-like cells from the anterior foregut endoderm cells}

After the thyroid endoderm stage, IGF1, KI and high concentrations of hTSH which could push the endodermal cells to thyroid cells were used for further differentiation. After expression of Nkx2.1 and Pax8 at the onset of thyroid development, thyroglobulin ( $\mathrm{Tg}, \mathrm{a}$ precursor of thyroxine), thyroperoxidase (TPO, needed for thyroid 

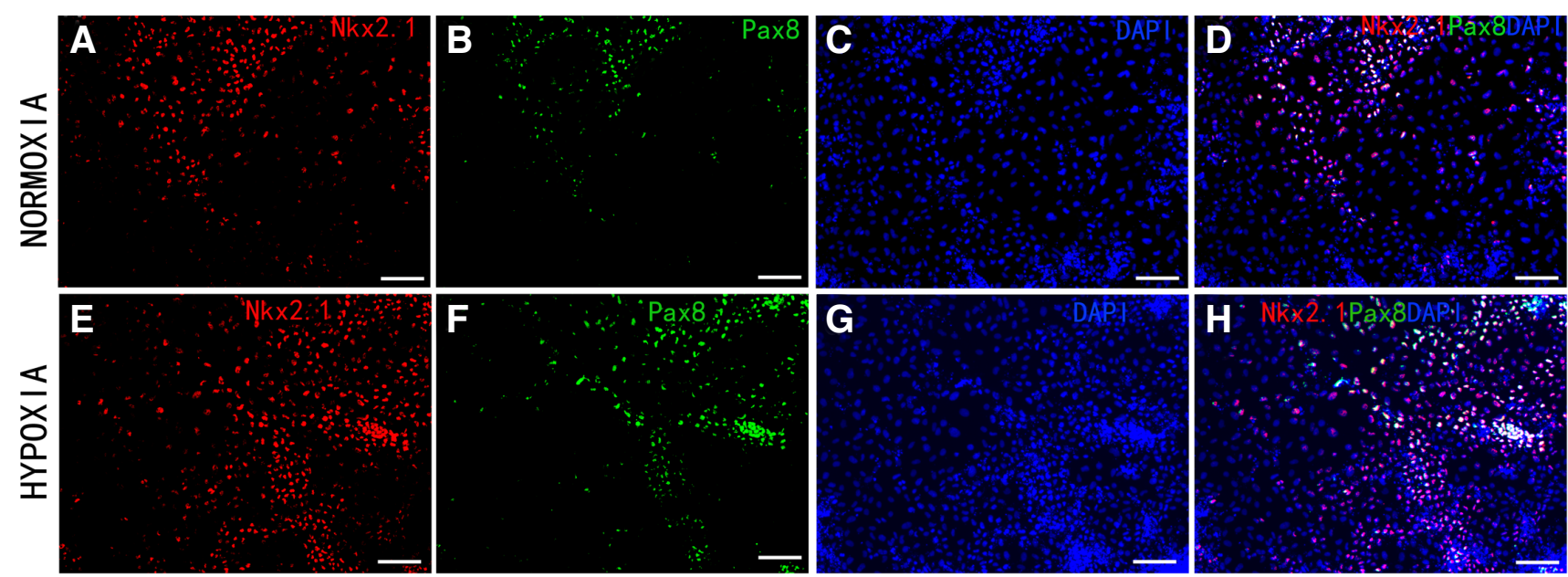

I
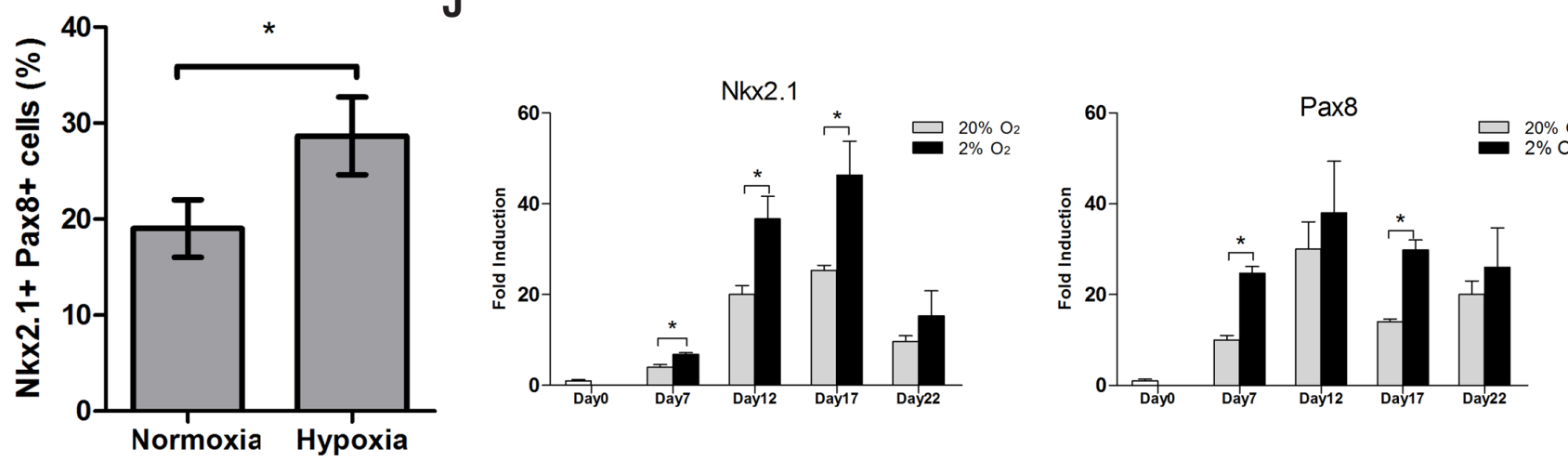

Fig. 3. Hypoxia enhances the expression of the thyroid transcription markers. (A-H) Representative images of double immuno-fluorescent staining for Nkx2.1 and Pax8 on day 15 of the differentiation process under hypoxia and normoxia. Scale bars, $100 \mu \mathrm{m}$. (I) Percent of Nkx2.1+ Pax8+ cells in hypoxic and normoxic culture conditions. Significant differences exist between the two culture conditions. ${ }^{*}(\mathbf{p}<0.05)$. (J) Expression levels of the thyroid transcription markers Nkx2.1 and Pax8 relative to undifferentiated miPS cells (day0) under hypoxic (black bar) and normoxic conditions (gray bar) by quantitative real-time PCR. Data are from three independent experiments and $\mathrm{p}<0.05\left({ }^{*}\right)$ indicates significant differences between groups.

hormone synthesis), sodium/iodide symporter (NIS, transport I- for synthesis of thyroid hormone) and thyroid stimulating hormone receptor (TSHR) were regarded as the thyroid-specific markers for mature and functional thyroid follicular cells (Lin et al., 2003; Arufe et al., 2006). In our study, TPO, NIS and TSHR were ex-
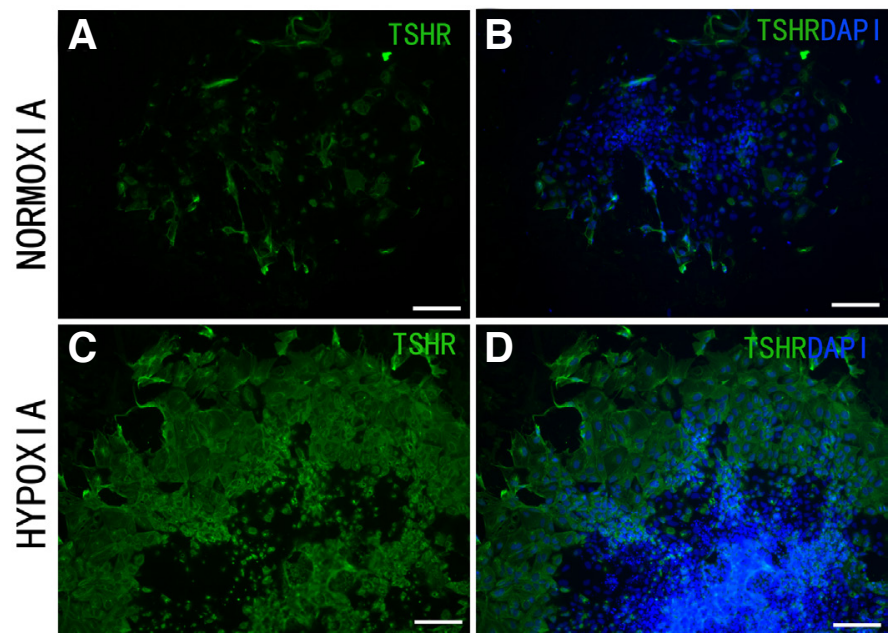

pressed by the induction protocol and their expression as well as that of Nkx2.1 and Pax8, were significantly higher under hypoxia $(p<0.05$, Fig. 6I). But the expression of $\mathrm{Tg}$ was not detected at any time point in this study.

Co-expression of NIS and TSHR is an exclusive characteristic of functional thyrocytes, so we measured NIS and TSHR protein at the end of differentiation and the polygonal glandular epithelium like cells which were positive for NIS and TSHR grew in spreading clusters under both conditions on day 22 (Fig. 6A-H). These cells could be regarded as the thyroid like cells and appeared in bigger pools with hypoxia. The percentage of NIS+TSHR+ cells under hypoxic condition was significantly higher than under normoxic condition (Fig. 6J, $p<0.05$ ). Western blot showed higher expression of NIS and TSHR after differentiation under hypoxia (Fig. $6 \mathrm{~K})$. For the function analysis, the radioactive iodide uptake of the

Fig. 4. Representative images of immuno-fluorescent staining forTSHR on day $\mathbf{1 0}$ of the differentiation process. (A) TSHR-positive cells (green) in normoxic culture (B) merged picture with DAPI. (C) TSHR-positive cells in hypoxic culture and (D) merged picture with DAPI. TSHR was expressed at the early stage of differentiation in the periphery of expanded EBs and showed stronger expression under hypoxia. Scale bars, $100 \mu \mathrm{m}$. 

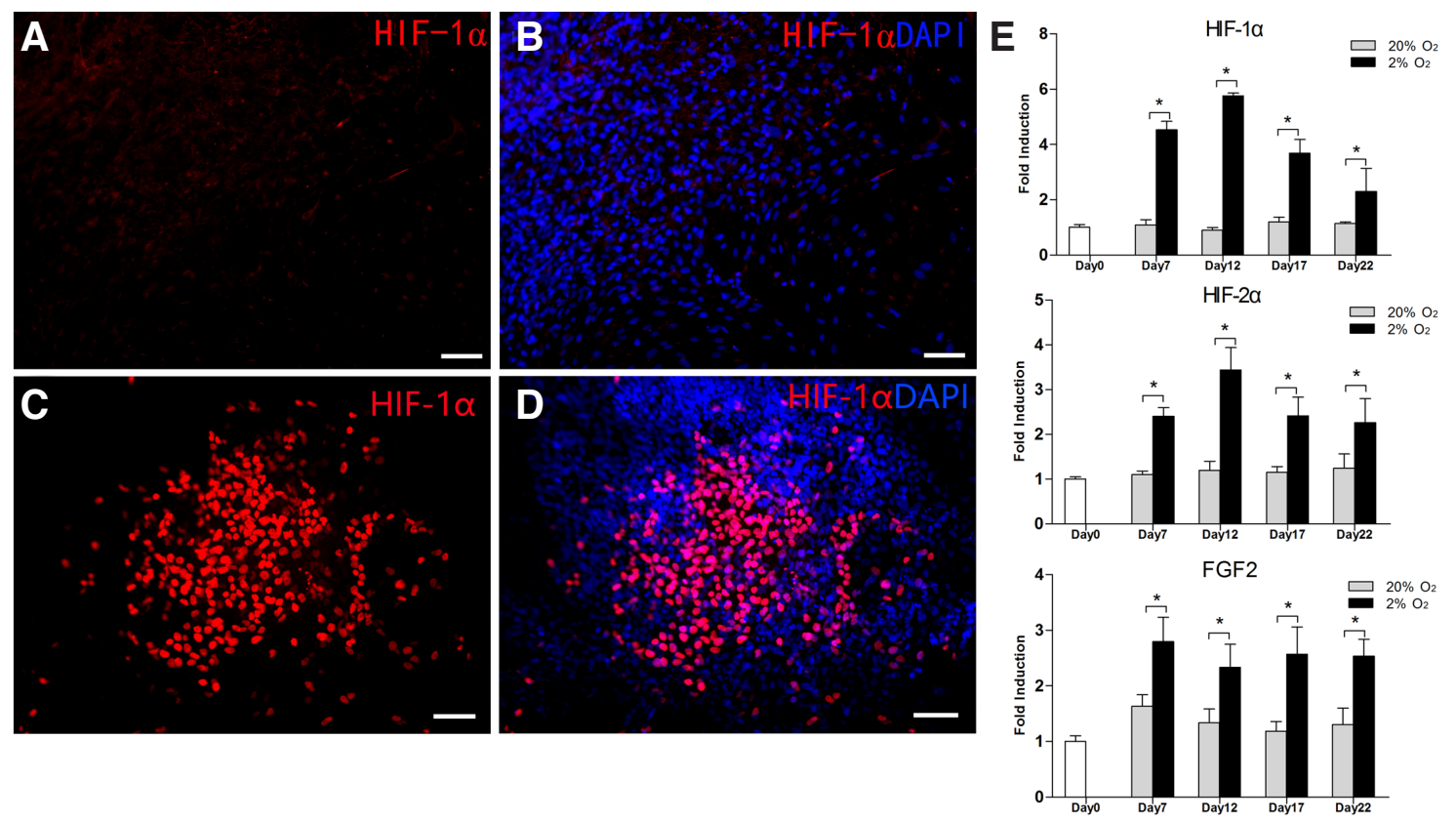

Fig. 5. Hypoxia increases the expression of HIFs and its downstream gene FGF2 during the thyroid differentiation. (A-D) Representative images of immuno-fluorescent staining for HIF-1 $\alpha$ on day 10 of the differentiation process under normoxia $(\mathbf{A}, \mathbf{B})$ and hypoxia (C,D). Scale bars, 100 um. (E) Expression levels of HIF-1 $\alpha, H I F-2 \alpha$ and $F G F 2$ relative to undifferentiated miPS (day0) cells under hypoxic (black bar) and normoxic conditions (gray bar) by quantitative real-time PCR. Data are from three independent experiments and $\mathrm{p}<0.05\left({ }^{*}\right)$ indicates significant differences between groups.
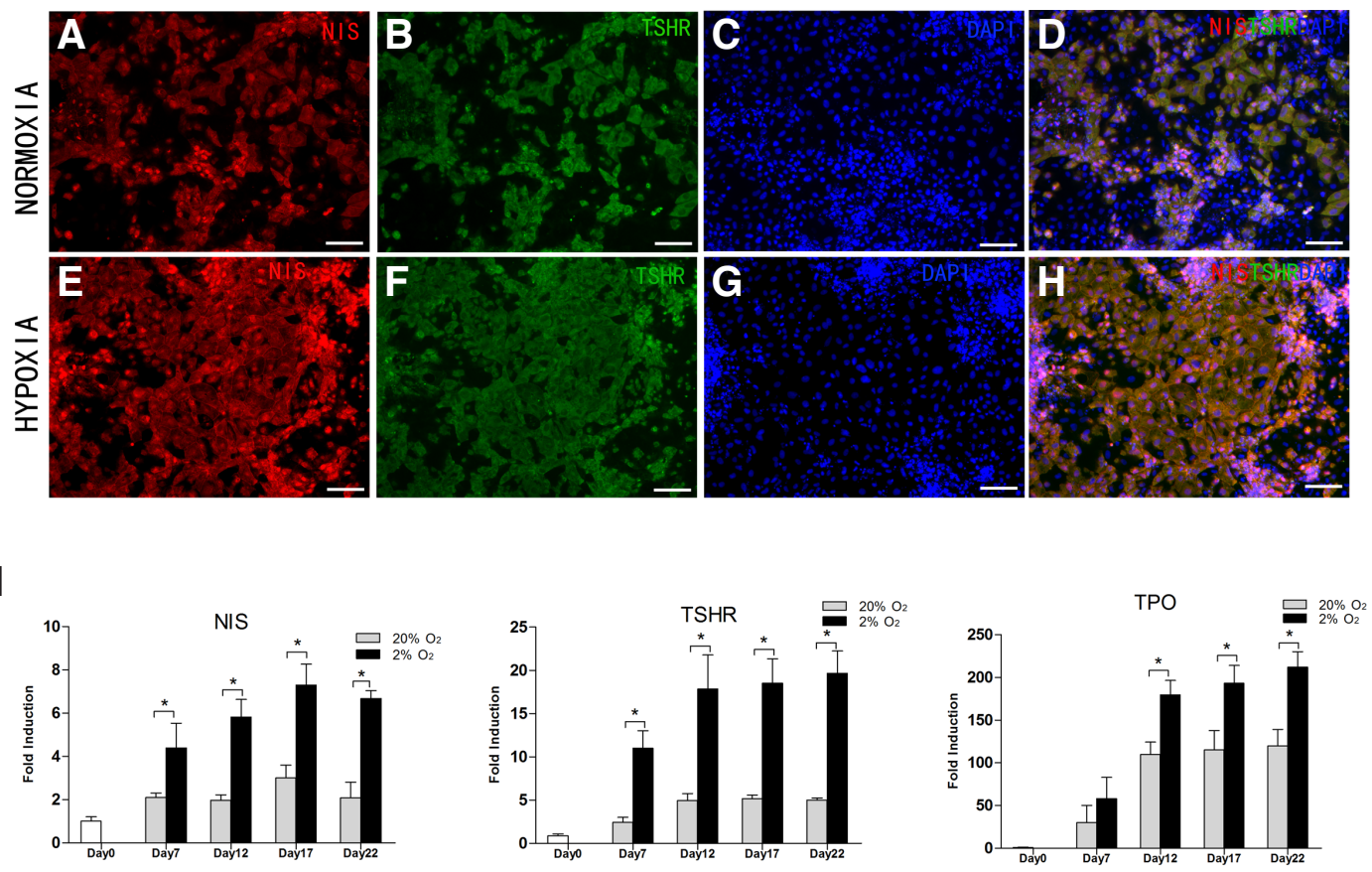

J

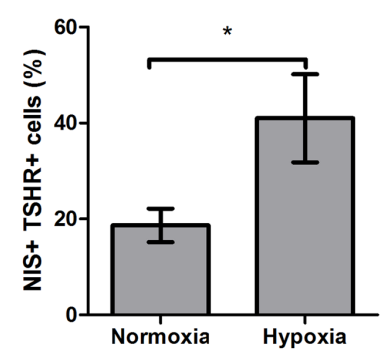

K

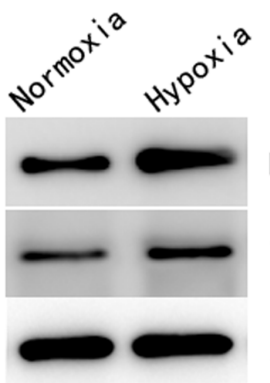

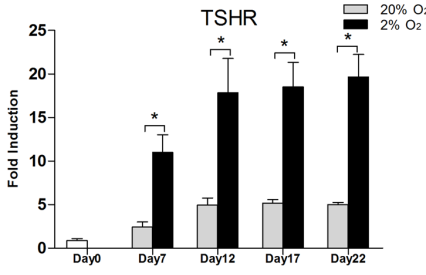

$\mathbf{L}$

NIS

TSHR

$\beta$-actin

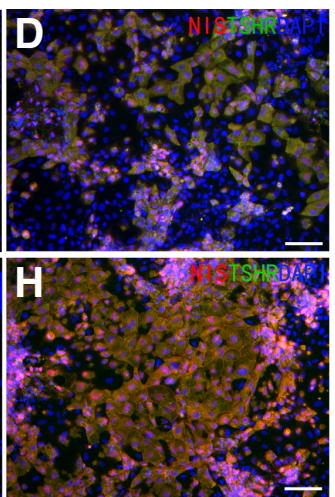

Fig. 6. Hypoxia promotes the induction of thyroid-like cells. (A-H) Representative images of double immuno-fluorescent staining TSHR and NIS on day 22 of the differentiation process under hypoxia and normoxia. The results showed the polygonal glandular epithelium like cells which were positive for NIS and TSHR grew in spreading clusters. Scale bars, 100 um. (I) Expression levels of the thyroid specific markers NIS, TSHR and TPO relative to undifferentiated miPS cells (day0) under hypoxic (black bar) and normoxic conditions (gray bar) by quantitative real-time PCR. (J) Percent TSHR+ $\mathrm{NIS}+$ cells in hypoxic and normoxic culture conditions. Significant differences exist between the two culture conditions. ${ }^{*}(\mathrm{p}<0.05)$. (K) Western blot analysis on day 22 of differentiation. $\beta$-actin was an internal control. (L) Radioactive iodide uptake after 22 days of differentiation and undifferentiated miPS cells were the control. Data are from three independent experiments performed in triplicate and $\left.p<0.05 \quad{ }^{*}\right)$ indicates significant differences between groups. 
differentiated cells was measured at the end of the experiment. We observed that I-uptake ability of the cells could be induced by our differentiation protocol under both oxygen conditions (Fig. $6 \mathrm{~L})$. Since the basal level of iodide uptake with the addition of NIS blocker sodium perchlorate was stable, the iodide uptake of the cells differentiated under hypoxia was significantly higher than under hypoxia (Fig. 6L, $p<0.05$ ).

\section{Discussion}

Thyroid deficiency is common and about $12 \%$ of the population in US may suffer the thyroid related conditions during lifetime (Sewell et al., 2014; Agrawal et al., 2015). There have been lots of studies about stem cell technologies which can be the key tools for tissue engineering and regenerative medicine to treat this condition in the recent years. We optimized a differentiation protocol with non-Nkx2.1/Pax8 modified iPS cells which were considered safer in clinical application. Hypoxia is considered to be associated with some pathological states, such as ischemia, inflammation and some cancers (Semenza, 2001). For example in the thyroid related field, Warner S. Simonides' study demonstrated that hypoxia may reduce metabolic rate in the tissue during hypoxic-ischemic injury through HIF-1 and DIO3 mediated thyroid hormone signaling regulation (Simonides et al., 2008). However, there was no report about the effect of oxygen tension on thyroid differentiation and thyroid hormone release. We mimicked $2 \%$ oxygen tension at EB induction and found that EB size and number did not differ under hypoxic or normoxic conditions (Fig. 1). Although this result was unexpected to some extent, our data for EB adhesion and outgrowth are similar to other reports (Bae et al., 2012; Garita-Hernandez et al., 2013; Lee et al., 2012) and this suggests a promoting effect of hypoxia. Gelatin is commonly used to coat the culture plates and dishes for cell growth and differentiation due to its beneficial physical and biochemical properties. Our protocol also use gelatin coated culture plates for EB attachment and further differentiation. However, the cells can only form 2D monolayer on the gelatin coated plates. Maybe matrigel, collagen or certain type of hydrogel can be used in further study for the formation of 3D structure.

Ectoderm, mesoderm, and endoderm are within EBs derived from iPS cells (Poh et al., 2014) and thyroid cells arise from a specific domain of the anterior foregut endoderm which develops from the definitive endoderm (DE) during embryogenesis (Grapin-Botton et al., 2000). Therefore, we transformed EBs into DE with high concentrations of Activin $A$ and supplemented differentiation medium with BMP and TGF- $\beta$ signaling inhibitors to achieve anteriorization of derived DE. The originally formed EBs were trypsinized into single cells in our modified protocol so that the cells could be sufficiently exposed to Activin A and other factors. We found that the formation of EBs was difficult for murine iPS cells without serum, but serum is considered a poor inducer of endoderm (Kubo et al., 2004). Therefore, we used the gradually reduced FBS in endodermal induction. In this stage, we proved that low oxygen increased expression of the endoderm-specific markers Gata4 and Foxa2 and this result indicated that hypoxia may take effect from the early differentiation of thyroid cells. We saw no similar changes for Sox17 and why this occurred is not clear. With immuno-fluorescent staining, we noted that cells expressing Foxa2 (important transcription factor associated with development of endoderm-derived tissues) was identified in the periphery of expanded EBs due to more exposure to differentiation medium. This also suggested the importance of EB attachment and outgrowth during differentiation. Meanwhile, early expression of TSHR at a similar area to Foxa2 illustrated an important role of TSH in early-mid stages and enhancement by hypoxia. Nkx2.1 and Pax8 are key regulators of thyroid development (Altmann et al., 2005; Di Palma et al., 2003) and Nkx2.1 or Pax8 knock-out mice may manifest thyroid agenesis and congenital hypothyroidism occur in the patients with mutations of these two genes (Krude et al., 2002; Macchia et al., 1998). We found more Nkx2.1+Pax8+ cells which are thought to have the potential to become thyroid cells under hypoxic culture. Such superiority due to hypoxia may directly result in better thyroid differentiation.

During the further thyroid induction, reduced expression of endodermal markers (Fig. 3) confirmed a change in maturity of endoderm cells in differentiation. At the end of our experiment, cells with the polygonal shape were observed and all thyroidspecific markers could be detected via gene and protein analysis except for Tg. This result is unexpected and similar with the thyroid differentiation reported by Maria C. Arufe et al., (Arufe et al., 2006). Although Tg expression is considered to be associated with serum and Tg secretion is controlled by TSH (Lin et al., 2003), some other factors which need further investigation may be required for $\mathrm{Tg}$ production and thyroid hormone synthesis. The larger amount of the cells which characteristically co-expressed NIS and TSHR showed the ultimate promotion of thyroid differentiation under hypoxia. In addition, we found the expression of Nkx2.1 and Pax8 in the later differentiation period. The sustained expression of these two thyroid transcription factors indicated the cells derived from iPS cells could keep thyroid differentiation potential during the entire differentiation process even in the end. As NIS-mediated iodide uptake is a crucial step for thyroid hormone synthesis and plays an important role in thyroid function (Cazarin et al., 2014), the iodine uptake capacity of the cells was estimated for functional comparison between the different oxygen conditions. Our study demonstrated that hypoxia could also increase the functional I- uptake of the differentiated cells and this result reconfirmed the promotion effect of hypoxia in thyroid differentiation.HIFs are considered to be important transcription factors activated and stabilized by low oxygen condition below $21 \% \mathrm{O}_{2}(\mathrm{Ng}$ et al., 2010 . HIFs are heterodimer complexes constituted by two subunits (Groenman et al., 2007). When exposed to low oxygen, the alpha-subunit which is easily degraded in normoxia accumulates, binds to the beta-subunit and transactivates multiple downstream genes which contain the hypoxia response elements and are involved in embryonic development (Saini et al., 2008). Our study also demonstrated that this mechanism may work in the thyroid differentiation. Greater expression of HIF- $1 \alpha$ and HIF- $2 \alpha$ at all time points together with FGF2 which was a direct transcriptional target of HIFs (Simon et al., 2008) and played an important role in specifying the thyroid lineage (Kurmann et al., 2015) revealed their possible involvement in this promotion by hypoxia. However, because the detail molecular mechanism of thyroid differentiation from murine iPS cells still remains unknown, the topics about whether other mechanisms or factors may get involved in this promotion need our further investigation. 


\section{Conclusion}

We have performed the thyroid differentiation from murine iPS cells under both hypoxic and normoxic conditions by using a new method. We offer the first evidence of the influence of thyroid induction by oxygen tension. Morphology, gene, protein and function analysis suggest that hypoxia promoted adhesion and outgrowth of EBs derived from murine iPC cells, and enhanced endodermal induction and thyroid differentiation. HIFs mediated regulation of FGF2 may get involved in this promotion and our data offer a foundation for understanding thyroid development and a potentially efficient approach for cell therapy.

\section{Materials and Methods}

\section{Maintenance of mouse iP cells in culture}

A mouse induced pluripotent stem cell line (mouse primary iPS cellsWP5) was purchased from Stemgent (08-0007; Cambridge, MA) and it was generated from unmodified mouse embryonic fibroblasts (Meissner et al., 2007). The mouse iPS cells were maintained on feeder cells (irradiated mouse embryonic fibroblast, MEF) in miPSC cell culture medium composed of knockout DMEM (Gibco, Grand Island, NY), 15\% (v/v) embryonic stem cell-qualified fetal bovine serum (FBS, Gibco), 1\% (v/v) non-essential amino acids (NEAA, Gibco), 1\% (v/v) L-glutamine (Gibco), $300 \mu \mathrm{M} \beta$-mercaptoethanol (Sigma-Aldrich St.Louis, MO) and $500 \mathrm{U} \mathrm{ml}^{-1}$ Stemfactor recombinant mouse LIF (Stemgent). Cells were incubated at $37{ }^{\circ} \mathrm{C}$ under $5 \% \mathrm{CO}_{2}$ and $20 \% \mathrm{O}_{2}$.

\section{Thyroid differentiation from miPS cells}

Hypoxic culture conditions were created using a Thermo Scientific incubator (HERAcell 150i, Waltham,MA). Cells were incubated in normoxic $(20 \%$ $\left.\mathrm{O}_{2}\right)$ and hypoxic condition $\left(2 \% \mathrm{O}_{2}\right)$ at the initiation of differentiation and these oxygen tension conditions were maintained throughout the experiment.

Definitive endoderm Formation. Before embryoid body (EB) induction, cells were dissociated with $0.05 \%$ trypsin for 3 mins and incubated on $0.1 \%$ gelatin coated-culture dishes for $45 \mathrm{~min}$ at $37^{\circ} \mathrm{C}$ to separate MEF feeder cells. Then, miPS cells were transferred into $60-\mathrm{mm}$ culture-grade petri dishes coated with $2 \%$ agar $\left(1 \times 10^{5}\right.$ cells $\left.\mathrm{mL}^{-1}\right)$ for self-aggregation. EB induction medium was composed of Iscove's Modified Dulbecco's Medium (IMDM, Gibco), 5\% (v/v) PFHM-II Protein-Free Hybridoma Medium (Gibco), 15\% stem cell-qualified FBS (Gibco), 1\% NEAA (Gibco), 1\% L-glutamine (Gibco), $100 \mu \mathrm{M} \beta$-mercaptoethanol (Sigma-Aldrich) and 0.5 $\mathrm{mM}$ ascorbic acid (Sigma-Aldrich). After $60 \mathrm{~h}$ in suspension culture, EBs were harvested with a $40-\mu \mathrm{m}$ cell strainer and trypsinized $\left(1 \mathrm{~min}, 37^{\circ} \mathrm{C}\right)$ into single cells which were subsequently plated into definitive endoderm induction medium consisting of 75\% (v/v) IMDM (Gibco), 25\% (v/v) Ham's Modified F12 medium (Cellgro, Manassas, VA), 10\% stem cell-qualified FBS, $5 \%$ (v/v) knockout serum replacement medium (KSR, Gibco), 1\% NEAA, $1 \%$ L-glutamine, $100 \mu \mathrm{M} \beta$-mercaptoethanol, $0.5 \mathrm{mM}$ ascorbic acid, $5 \mu \mathrm{g}$ $\mathrm{mL}^{-1}$ transferrin (Sigma-Aldrich), $5 \mu \mathrm{g} \mathrm{mL}^{-1}$ insulin, $50 \mathrm{ng} \mathrm{mL}^{-1}$ recombinant Activin A (R\&D Systems, Minneapolis, MN) and $100 \mu \mathrm{U} \mathrm{mL}^{-1}$ recombinant human thyroid-stimulating hormone (hTSH, Fitzgerald Industries, Acton, MA). After $12 \mathrm{~h}$, culture medium was changed to definitive endoderm induction medium supplemented with 3\% (v/v) FBS and 10\% KSR. After 36 $\mathrm{h}$, EBs were transferred to serum-free endoderm induction medium with $15 \% \mathrm{KSR}$ and incubated for another $24 \mathrm{~h}$.

Thyroid endoderm formation. After $120 \mathrm{~h}$ ( 5 days) of differentiation, the EBs were harvested again and re-plated in $0.1 \%$ gelatin coated 24 - and 6-well culture plates (5-8 EBs/cM ${ }^{2}$ ) for adhesion culture in anterior definitive endoderm differentiation medium composed of $75 \%$ IMDM (Gibco), 25\% Ham's Modified F12 medium (Cellgro), 1\% stem cell-qualified FBS (Gibco), 15\% KSR, 1\% NEAA, 1\% L-glutamine, 100 $\mu \mathrm{M} \beta$-mercaptoethano, $0.5 \mathrm{mM}$ ascorbic acid, $5 \mu \mathrm{g} \mathrm{mL}^{-1}$ transferrin, $5 \mu \mathrm{g} \mathrm{mL}^{-1}$ insulin, $100 \mu \mathrm{U} \mathrm{mL}^{-1}$

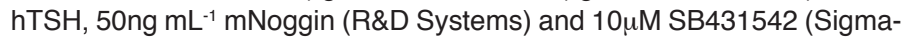

Aldrich). For the EB adhesion test, we counted the number of the attached EBs on the culture plates after two days adhesion culture and calculated the percentage in the initially seeded EBs. After total 7 days differentiation, the medium was switched to thyroid differentiation medium (75\% IMDM, 25\% Ham's Modified F12 medium, 15\% KSR, 1\% NEAA, 1\% L-glutamine, $100 \mu \mathrm{M} \beta$-mercaptoethanol, $0.5 \mathrm{mM}$ ascorbic acid, $10 \mu \mathrm{g} \mathrm{mL}^{-1}$ transferrin, $7.5 \mu \mathrm{g} \mathrm{mL}^{-1}$ insulin, $1 \mathrm{mU} \mathrm{mL}^{-1} \mathrm{hTSH}$ ) supplemented with $10 \mathrm{ng} \mathrm{mL}^{-1} \mathrm{mBMP}^{-1}$ (R\&D Systems), 500ng mL ${ }^{-1} \mathrm{mFGF}$ (R\&D Systems) and 100 $\mathrm{ng} \mathrm{mL}^{-1} \mathrm{FGF} 10$ (R\&D Systems). The cells were grown for another 5 days. In addition, to compare the outgrowth of EBs under both oxygen conditions, the average radius of expanded EBs was measured (the distance from the center of the cells to the periphery in multiple directions) 4 days after reattachment.

Thyroid differentiation. On day 12 of differentiation, culture medium was changed to thyroid differentiation medium supplemented with $50 \mathrm{ng}$ $\mathrm{mL}^{-1}$ recombinant mouse IGF1 (R\&D Systems). Cells were incubated for 10 days and on differentiation day $16, \mathrm{KI}(100 \mu \mathrm{M}$, Sigma-Aldrich) was added into the medium.

\section{Immuno-fluorescence staining}

Cells cultured in 24-well plates were stained on the scheduled time points. After fixing samples in $4 \%(\mathrm{v} / \mathrm{v})$ paraformaldehyde for $15 \mathrm{~min}$ on ice, some samples were permeabilized with $1 \%(\mathrm{v} / \mathrm{v})$ triton $\mathrm{X}-100$ for nuclear staining. After three washings in PBS, samples were incubated in serum-free protein blocking (Dako) solution at room temperature for $1 \mathrm{~h}$ and then with primary antibodies (Dako) overnight at $4{ }^{\circ} \mathrm{C}(300 \mu \mathrm{L} /$ well). Then, cells were washed and incubated in secondary antibodies for 1.5 $\mathrm{h}$ at room temperature in the dark. Nuclei were counterstained with DAPI (1:500, Invitrogen) and samples were mounted with mounting medium (Vectashield, Burlingame, CA). Samples were incubated in secondary antibody solution only for negative controls. Images were taken under a fluorescent microscope (Leica DMI3000B) and analyzed using ImageJ 1.46r. Four replicates were performed and five random fields of each assay were taken for analysis

The antibodies we used: polyclonal rabbit anti-sodium iodide symporter (NIS) antibody (sc-134515, Santa Cruz Biotechnology, CA, 1:50), monoclonal mouse anti-TSH receptor antibody (sc-53542, Santa Cruz Biotechnology, CA, 1:50), monoclonal rabbit anti-Foxa2 antibody (ab108422, Abcam, 1:350), monoclonal mouse anti-Pax8 antibody (MA1-117, Invitrogen, 1:100), monoclonal rabbit anti-Nkx2.1 antibody (ab76013, Abcam, 1:300), monoclonal mouse anti-HIF-1 $\alpha$ antibody (sc-13515, Santa Cruz, 1:50), goat anti-rabbit IgG (A-11012, Alexa Fluor ${ }^{\circledR}$ 594-conjugated; Invitrogen), goat anti-mouse IgG (A-11001, Alexa Fluor ${ }^{\circledR}$ 488-conjugated; Invitrogen), donkey anti-mouse lgG (A-21203, Alexa Fluor ${ }^{\circledR}$ 594-conjugated; Invitrogen).

\section{Western blot analysis}

After washing, cell protein from 6-well culture plates was isolated with RIPAlysis buffer containing $1 \%$ proteinase/phosphatase inhibitor. Samples were centrifuged to remove insoluble material and protein was quantified with a BCA protein quantification kit. Samples were mixed with $2 x$ loading buffer with $\beta$-mercaptoethanol and boiled for denaturation $\left(95^{\circ} \mathrm{C}\right.$ for $5 \mathrm{~min}$ ). Then, $\sim 20 \mathrm{\mu g}$ protein from each sample was separated via 10\% SDS-PAGE and transferred to nitrocellulose membranes. Nonspecific protein-binding sites were blocked with $5 \%$ skim milk and samples were incubated in primary antibody overnight at $4^{\circ} \mathrm{C}$. Next, samples were washed with $0.1 \%$ Tween-20 and incubated with secondary antibody for $1 \mathrm{~h}$. Finally, chemiluminescent reagent (GE) was applied and immunoreactive bands were visualized with a luminescent image analyzer (ImageQuant400, GE).

The antibodies we used: polyclonal rabbit anti-Gata4 antibody (ab84593, Abcam, 1:1000), polyclonal goat anti-Foxa2 antibody (ab108422, Abcam, 1:500), monoclonal mouse anti-HIF-1 $\alpha$ antibody (ab16066, Abcam, 1:1000), polyclonal goat anti-NIS antibody (sc-48052, Santa Cruz Biotechnology, 1:500), monoclonal mouse anti-TSH receptor antibody (sc-53542, Santa Cruz Biotechnology, CA, $1: 2000)$, monoclonal mouse anti- $\beta$-actin antibody (ab8226, Abcam, 1:5000), goat anti-rabbit IgG (HRP-conjugated; 32460 Invitrogen), rabbit anti-goat IgG (HRP-conjugated;31402, Invitrogen), goat 
anti-mouse IgG (HRP-conjugated; 31430, Invitrogen).

\section{RNA extraction}

Total RNA was extracted from samples cultured in 6-well plates with PerfectPure RNA fibrous tissue kit (5 Prime Inc., Gaithersburg, MD) according to the manufacturer's instructions. Nucleic acid concentrations were measured with a Nanodrop 2000 spectrophotometer (Thermo-scientific, Waltham, MA) and isolated RNA was stored at $-80{ }^{\circ} \mathrm{C}$ for later analysis. RNA was reverse transcribed to cDNA using a high-capacity cDNA reverse transcription kit (Applied Biosystems, Foster City, CA).

\section{Quantitative real-time $P C R$ analysis}

cDNA (25 ng) from each sample was used for quantitative real-time PCR analysis with an ABI Prism 7300 PCR thermocycler (Applied Biosystems, Foster City, CA) with a SYBR Premix Ex Taq (Takara, Minamikusatsu, Japan). The housekeeping gene $\beta$-actin was used for normalization by calculating relative values of expression fold-changes using the $2^{-\Delta \Delta C t}$ method. Each sample was measured in triplicate and data are from 3 independent experiments. The primer sequences were shown as follows: TSHR (forward), 5'-GTCTGCCCAATATTTCCAGGATCTA-3'; TSHR (reverse), 5'-GCTCTGTCAAGGCATCAGGGT-3'; NIS (forward), 5'-AGCTGCCAACACTTCCAGAG-3'; NIS (reverse), 5'-GATGAGAGCACCACAAAGCA-3'; TPO (forward), 5'-ACAGTCACAGTTCTCCACGGATG-3'; TPO (reverse), 5'-ATCTCTATTGTTGCACGCCCC-3'; Tg (forward), 5'-GTCCAATGCCAAAATGATGGTC-3'; Tg (reverse), 5'-GAGAGCATCGGTGCTGTTAAT-3'; Pax8 (forward), 5'-CAGCCTGCTGAGTTCTCCAT-3'; Pax8 (reverse), 5'-CTGTCTCAGGCCAAGTCCTC-3'; Gata4 (forward), 5'-GAGGGTGAGCCTGTATGTAATGC-3'; Gata4 (reverse), 5'-TGGCATTGCTGGAGTTACCG-3'; Nkx2.1 (forward), 5'- GGCGCCATGTCTTGTTCT-3'; Nkx2.1 (reverse), 5'-GGGCTCAAGCGCATCTCA-3'; Foxa2 (forward), 5'-CAGAACTCCATCCGCCACTC-3'; Foxa2 (reverse), 5'-CTTCAGTGCCAGTTGCTTCTCA-3'; Sox17 (forward), 5'-GCCATCAGAACACCAAAACCA-3'; Sox17 (reverse), 5'-GCCATCAGAACACCAAAACCA-3'; HIF-1 $\alpha$ (forward), 5'-ACCTTCATCGGAAACTCCAAAG-3'; HIF- $1 \alpha$ (reverse), 5'-CTGTTAGGCTGGGAAAAGTTAGG-3'; MOP2 (forward), 5'-CTGAGGAAGGAGAAATCCCGT-3'; MOP2 (reverse), 5'-TGTGTCCGAAGGAAGCTGATG-3'; FGF2 (forward), 5'-TGGTGACCACAAGCTGAATG-3'; FGF2 (reverse), 5'-TCCCTTGATAGACACAACTCCTC-3'; $\beta$-actin (forward), 5'-AGAGGGAAATCGTGCGTGAC-3'; $\beta$-actin (reverse), 5'-TGCCACAGGATTCCATACCC-3'.

\section{Radioactive iodide uptake}

After washing in PBS solution, the cells were incubated in IMDM medium containing $1 \mathrm{mU} \mathrm{mL}^{-1} \mathrm{hTSH}$ and $20 \mu \mathrm{M}$ sodium iodide supplemented with $10 \mu \mathrm{Ci} / \mu \mathrm{l}$ carrier-free $\mathrm{Na}^{125}$ for $45 \mathrm{~min}$ at $37^{\circ} \mathrm{C}$ under $5 \% \mathrm{CO}_{2}$ and $20 \% \mathrm{O}_{2}$, with or without $40 \mu \mathrm{M}$ sodium perchlorate. Then the radioactive medium was removed and the cells were washed again with PBS. To measure the radioactivity, 95\% cold ethanol was added and the amount of ${ }^{125} I^{-}$was quantitated by a $\gamma$-counter. DNA was extracted with Puregene kit (Gentra Systems) and measured with a Nanodrop 2000 spectrophotometer (Thermo-scientific) in parallel experiments. The values of iodide uptake were expressed as picomoles per microgram of DNA.

\section{Data analyses}

Data are means \pm SD and SPSS (v19.0) software was used for statistical analysis. Group comparisons were performed using the Student's t-test and statistical differences were considered to be significant when $p \leq 0.05$.

\section{Acknowledgment}

This work was supported by Science and Technology Foundation of Shanghai Jiao Tong University Medical School (Grant No. 13xj22003) and Shanghai Health Bureau Key projects of scientific research fund(Grant No. 20124015). The authors are grateful to Dr. Hualin Yi, Dr. Wei Gong and Dr. Ping Dong for all the help in this research.

\section{References}

AGRAWAL P, PHILIP R, SARAN S, GUTCH M, RAZI M S, AGROIYA P, GUPTA K (2015). Congenital hypothyroidism. Indian J Endocrinol Metab 19: 221-227.

ALTMANN A, SCHULZR B, GLENSCH G, ESKERSKI H, ZITZMANN S, EISENHUT M, HABERKORN U (2005). Effects of Pax8 and TTF-1 thyroid transcription factor gene transfer in hepatoma cells: imaging of functional protein-protein interaction and iodide uptake. J Nucl Med 46: 831-839.

ANTONICA F, KASPRZYK D F, OPITZ R, IACOVINO M, LIAO X H, DUMITRESCU A M, REFETOFF S, PEREMANS K, MANTO M, KYBA M et al.,2012). Generation of functional thyroid from embryonic stem cells. Nature 491: 66-71.

ARUFE M C, LU M, KUBO A, KELLER G, DAVIES T F, LIN R Y (2006). Directed differentiation of mouse embryonic stem cells into thyroid follicular cells. Endocrinology 147: 3007-3015.

ARUFE M C, LU M, LIN R Y (2009). Differentiation of murine embryonic stem cells to thyrocytes requires insulin and insulin-like growth factor-1. Biochem Biophys Res Commun 381: 264-270.

BAE D, MONDRAGON-TERAN P, HERNANDEZ D, RUBAN L, MASON C, BHATTACHARYA S S, VERAITCH F S (2012). Hypoxia enhances the generation of retinal progenitor cells from human induced pluripotent and embryonic stem cells. Stem Cells Dev 21: 1344-1355.

CAZARIN J M, ANDRADE B M, CARVALHODP (2014). AMP-activated protein kinase activation leads to lysome-mediated $\mathrm{NA}(+) / \mathrm{I}(-)$-symporter protein degradation in rat thyroid cells. Horm Metab Res 46: 313-317.

Di PALMA T, NITSCH R, MASCIA A, NITSCH L, Di LAURO R, ZANNINI M (2003). The paired domain-containing factor Pax8 and the homeodomain-containing factor TTF-1 directly interact and synergistically activate transcription. $J$ Biol Chem 278: 3395-3402.

DUNWOODIE S L (2009). The role of hypoxia in development of the Mammalian embryo. Dev Cell 17: 755-773.

EZASHI T, DAS P, ROBERTS R M (2005). Low O2 tensions and the prevention of differentiation of hES cells. Proc Natl Acad Sci USA 102: 4783-4788.

FISCHER B, BAVISTER B D (1993). Oxygen tension in the oviduct and uterus of rhesus monkeys, hamsters and rabbits. J Reprod Fertil 99: 673-679.

GARITA-HERNANDEZ M, DIAZ-CORRALES F, LUKOVIC D, GONZALEZ-GUEDE I, DIEZ-LLORET A, VALDES-SANCHEZ M L, MASSALINI S, ERCEG S, BHATTACHARYASS (2013). Hypoxia increases the yield of photoreceptors differentiating from mouse embryonic stem cells and improves the modeling of retinogenesis in vitro. Stem Cells 31: 966-978.

GARRETAE, MELO E, NAVAJAS D, FARRE R (2014). Low oxygen tension enhances the generation of lung progenitor cells from mouse embryonic and induced pluripotent stem cells. Physiol Rep 2: e12075.

GRAPIN-BOTTON A, MELTON D A (2000). Endoderm development: from patterning to organogenesis. Trends Genet 16: 124-130.

GROENMAN F, RUTTER M, CANIGGIA I, TIBBOEL D, POST M (2007). Hypoxiainducible factors in the first trimester human lung. J Histochem Cytochem 55: 355-363.

HOLLOWELL J G, STAEHLING N W, FLANDERS W D, HANNON W H, GUNTER E W, SPENCER C A, BRAVERMAN L E (2002). Serum TSH, T(4), and thyroid antibodies in the United States population (1988 to 1994): National Health and Nutrition Examination Survey (NHANES III). J Clin Endocrinol Metab 87: 489-499.

KRUDE H, SCHUTZ B, BIEBERMANN H, von MOERS A, SCHNABEL D, NEITZEL H, TONNIES H, WEISE D, LAFFERTY A, SCHWARZ S et al.,2002). Choreoathetosis, hypothyroidism, and pulmonary alterations due to human NKX2-1 haploinsufficiency. J Clin Invest 109: 475-480.

KUBO A, SHINOZAKI K, SHANNON J M, KOUSKOFF V, KENNEDY M, WOO S, FEHLING H J, KELLER G (2004). Development of definitive endoderm from embryonic stem cells in culture. Development 131: 1651-1662.

KURMANN A A, SERRA M, HAWKINS F, RANKIN S A, MORI M, ASTAPOVA I, ULLAS S, LIN S, BILODEAU M, ROSSANT J et al.,2015). Regeneration of Thyroid Function by Transplantation of Differentiated Pluripotent Stem Cells. Cell Stem Cell 17: 527-542.

LEE S W, JEONG H K, LEE J Y, YANG J, LEE E J, KIM S Y, YOUN S W, LEE J, KIM W J, KIM K W et al.,2012). Hypoxic priming of mESCs accelerates vascular- 
lineage differentiation through HIF1-mediated inverse regulation of Oct4 and VEGF. EMBO Mol Med 4: 924-938.

LIN R Y, KUBO A, KELLER G M, DAVIES T F (2003). Committing embryonic stem cells to differentiate into thyrocyte-like cells in vitro. Endocrinology 144:2644-2649.

MA R, MORSHED S A, LATIF R, DAVIES T F (2015). Thyroid cell differentiation from murine induced pluripotent stem cells. Front Endocrinol (Lausanne) 6: 56.

MACCHIAP E, LAPIP, KRUDE H, PIRRO M T, MISSERO C, CHIOVATO L, SOUABNI A, BASERGA M, TASSI V, PINCHERAA et al.,1998). PAX8 mutations associated with congenital hypothyroidism caused by thyroid dysgenesis. Nat Genet 19:83-86.

MCLACHLANS M, RAPOPORTB (2004). Why measure thyroglobulin autoantibodies rather than thyroid peroxidase autoantibodies? Thyroid 14: 510-520.

MEISSNERA, WERNIG M, JAENISCHR (2007). Direct reprogramming of genetically unmodified fibroblasts into pluripotent stem cells. Nat Biotechnol 25: 1177-1181.

MILLMAN J R, TAN J H, COLTON C K (2009). The effects of low oxygen on selfrenewal and differentiation of embryonic stem cells. Curr Opin Organ Transplant 14: $694-700$

MOHYELDINA, GARZON-MUVDIT, QUINONES-HINOJOSAA(2010). Oxygen in stem cell biology: a critical component of the stem cell niche. Cell Stem Cell 7: 150-161.

MONDRAGON-TERAN P, LYE G J, VERAITCH F S (2009). Lowering oxygen tension enhances the differentiation of mouse embryonic stem cells into neuronal cells. Biotechnol Prog 25: 1480-1488.

MORA-CASTILLA S, TEJEDO J R, TAPIA-LIMONCHI R, DIAZ I, HITOS A B, CAHUANA G M, HMADCHAA, MARTIN F, SORIA B, BEDOYA F J (2014). Transient Downregulation of Nanog and Oct4 Induced by DETA/NO Exposure in Mouse Embryonic Stem Cells Leads to Mesodermal/Endodermal Lineage Differentiation. Stem Cells Int 2014: 379678.

MU D, HUANG R, LI S, MAX, LOU C, KUANG A (2012). Combining transfer of TTF-1 and Pax-8 gene: a potential strategy to promote radioiodine therapy of thyroid carcinoma. Cancer Gene Ther 19: 402-411.

NG K M, LEE Y K, CHAN Y C, LAI W H, FUNG M L, LI R A, SIU C W, TSE H F (2010). Exogenous expression of HIF-1 alpha promotes cardiac differentiation of embryonic stem cells. J Mol Cell Cardiol 48: 1129-1137.

POH Y C, CHEN J, HONG Y, YI H, ZHANG S, CHEN J, WU D C, WANG L, JIA Q, SINGH R et al.,2014). Generation of organized germ layers from a single mouse embryonic stem cell. Nat Commun 5: 4000.
PRADO-LOPEZ S, CONESA A, ARMINAN A, MARTINEZ-LOSA M, ESCOBEDOLUCEA C, GANDIA C, TARAZONA S, MELGUIZO D, BLESA D, MONTANER D et al.,2010). Hypoxia promotes efficient differentiation of human embryonic stem cells to functional endothelium. Stem Cells 28: 407-418.

SAINI Y, HARKEMA J R, LAPRES J J (2008). HIF1alpha is essential for normal intrauterine differentiation of alveolar epithelium and surfactant production in the newborn lung of mice. J Biol Chem 283: 33650-33657.

SEMENZA G L (2001). Hypoxia-inducible factor 1: oxygen homeostasis and disease pathophysiology. Trends Mol Med 7: 345-350.

SEWELL W, LIN R Y (2014). Generation of thyroid follicular cells from pluripotent stem cells: potential for regenerative medicine. Front Endocrinol (Lausanne) 5: 96

SHIN J M, KIM J, KIM H E, LEE M J, LEE K I, YOO E G, JEON Y J, KIM D W, CHAE $\mathrm{J}$ I, CHUNG H M (2011). Enhancement of differentiation efficiency of hESCs into vascular lineage cells in hypoxia via a paracrine mechanism. Stem Cell Res 7: 173-185.

SIMON M C, KEITH B (2008). The role of oxygen availability in embryonic development and stem cell function. Nat Rev Mol Cell Biol 9: 285-296.

SIMONIDES W S, MULCAHEY M A, REDOUT E M, MULLER A, ZUIDWIJK M J, VISSER T J, WASSEN F W, CRESCENZI A, DA-SILVA W S, HARNEY J et al.,2008). Hypoxia-inducible factor induces local thyroid hormone inactivation during hypoxic-ischemic disease in rats. J Clin Invest 118: 975-983.

TAKAHASHI K, TANABE K, OHNUKI M, NARITA M, ICHISAKA T, TOMODA K, YAMANAKAS (2007). Induction of pluripotent stem cells from adult human fibroblasts by defined factors. Cell 131: 861-872.

van OORSCHOT AA, SMITS A M, PARDALI E, DOEVENDANS P A, GOUMANS M $\mathrm{J}$ (2011). Low oxygen tension positively influences cardiomyocyte progenitor cell function. J Cell Mol Med 15: 2723-2734.

WION D, CHRISTEN T, BARBIER E L, COLES J A (2009). PO(2) matters in stem cell culture. Cell Stem Cell 5: 242-243.

YAMANAKA S (2008). Induction of pluripotent stem cells from mouse fibroblasts by four transcription factors. Cell Prolif 41 Suppl 1: 51-56.

ZACHAR V, PRASAD S M, WELI S C, GABRIELSEN A, PETERSEN K, PETERSEN $M B, F I N K T$ (2010). The effect of human embryonic stem cells (hESCs) long-term normoxic and hypoxic cultures on the maintenance of pluripotency. In vitro $\mathrm{Ce}$ Dev Biol Anim 46: 276-283. 


\section{Further Related Reading, published previously in the Int. J. Dev. Biol.}

The role of angiogenic growth factors in organogenesis

Enrico Crivellato

Int. J. Dev. Biol. (2011) 55: 365-375

http://dx.doi.org/10.1387/ijdb.103214ec

Sox17-dependent gene expression and early heart and gut development in Sox17-deficient mouse embryos

Sabine Pfister, Vanessa J. Jones, Melinda Power, Germaine L. Truisi, Poh-Lynn Khoo, Kirsten A. Steiner, Masami Kanai-Azuma, Yoshiakira

Kanai, Patrick P. L. Tam and David A. F. Loebel

Int. J. Dev. Biol. (2011) 55: 45-58

http://dx.doi.org/10.1387/ijdb.103158sp

Estrogen regulation of placental angiogenesis and fetal ovarian development during primate pregnancy

Eugene D. Albrecht and Gerald J. Pepe

Int. J. Dev. Biol. (2010) 54: 397-407

http://dx.doi.org/10.1387/ijdb.082758ea

A twist of insight - the role of Twist-family bHLH factors in development

Ralston M. Barnes and Anthony B. Firulli

Int. J. Dev. Biol. (2009) 53: 909-924

http://dx.doi.org/10.1387/ijdb.082747rb

Genetic disruption of the growth hormone receptor does not influence motoneuron survival in the developing mouse

Sean A Parsons, Glen B Banks, Jenny A Rowland, Karen T Coschigano, John J Kopchick, Michael J Waters and Peter G Noakes

Int. J. Dev. Biol. (2003) 47: 41-49

http://dx.doi.org/10.1387/ijdb.12653250

5 yr ISI Impact Factor $(2013)=2.879$
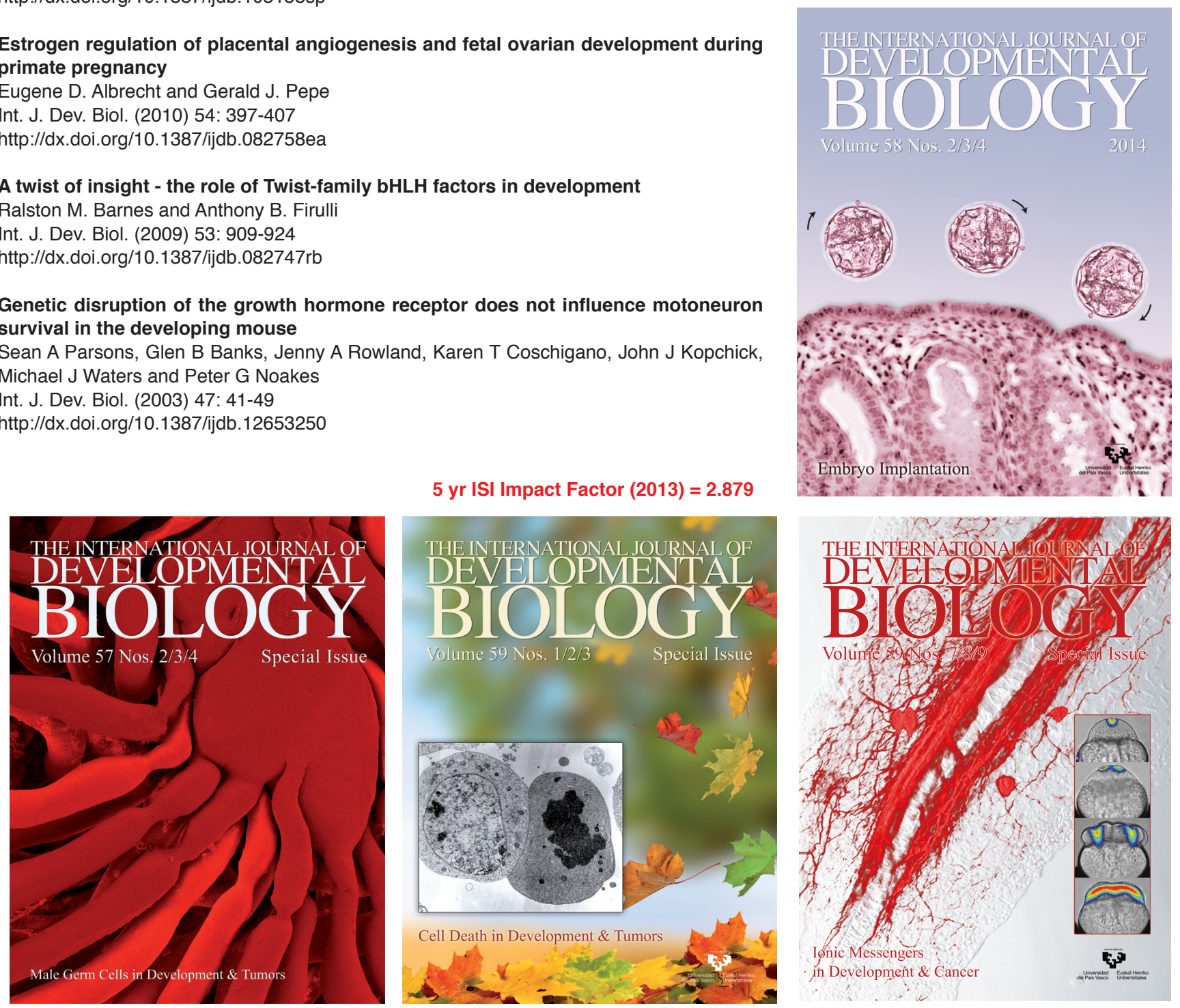